\title{
Revisão das espécies de Bithoracochaeta Stein (Diptera, Muscidae)
}

\author{
Henrique Cesar Gonçalves da Motta ${ }^{1}$ \\ Márcia Souto Couri ${ }^{1,2}$
}

\begin{abstract}
Revision of the species of Bithoracochaeta Stein (Diptera, Muscidae). Bithoracochaeta Stein, 1911 and eigth known species are redescribed: $B$. annulata Stein, 1911; B. atricornis Malloch, 1934; B. flavicoxa Malloch, 1934; B. leucoprocta (Wiedemann, 1830), B. maricaensis Couri \& Motta, 1994 , B. nigricornis Malloch, 1934; B. plumata Albuquerque, 1955; B. varicornis (Coquillett, 1900). The redescriptions of B. sociabilis Blanchard, 1937 and B. pacifera (Giglio-Tos, 1893) are not presented because no material was available. A key to identification of the redescribed species is presented.

KEY WORDS. Diptera, Muscidae, Bithoracochaeta, taxonomy, Neotropical
\end{abstract}

Bithoracochaeta Stein, 1911, gênero neotropical (uma espécie ocorrendo também no sul da América do Norte) é um Coenosiinae, Coenosiini (sensu CARVALHO 1989), caracterizado pela presença, na tíbia posterior, de pelo menos três cerdas medianas longas e finas nas faces anterior, ântero-dorsal e posterior, algumas espécies com uma cerda mediana adicional na face póstero-ventral e pela distribuição das cerdas dorsocentrais 1:2. De acordo com CARVALHO et al. (1993) compreende as seguintes espécies: $B$. annulata Stein, 1911, B. leucoprocta (Wiedemann, 1830), B. flavicoxa Malloch, 1934, B. nigricornis Malloch, 1934; B. pacifera (Giglio-Tos,1893); B. plumata Albuquerque, 1955; B. sociabilis Blanchard, 1937; B. varicornis (Coquillett, 1900). COURI \& MOTTA (1994) descreveram B. maricaensis e MOTTA \& COURI (no prelo) revalidaram B. atricornis Malloch, 1934. Com exceção de $B$. plumata e $B$. maricaensis, descritas com mais detalhes, as demais espécies são conhecidas principalmente por caracteres referentes à coloração, sendo o estudo de caracteres diagnósticos de fundamental importância para melhor caracterizá-las.

As espécies B. sociabilis Blanchard, 1937 e B. pacifera (Giglio-Tos, 1893) não foram incluídas nesta revisão pois o tipo da primeira se encontra perdido (in litteri Dr. Axle Bachmann, Museu Argentino de Ciências Naturais) e o da segunda está depositado no Museu de Torino cujos empréstimos estão suspensos temporariamente por motivo de mudança da coleção (in litteri Dr. Antonio Rolando, Universidade de Torino). No material examinado não foi possível identificar exemplares destas espécies.

O objetivo desta revisão é fornecer uma melhor caracterização das espécies de Bithoracochaeta e fornecer uma chave para a identificação das espécies.

1) Museu Nacional. Quinta da Boa Vista, São Cristóvão, 20940-040 Rio de Janeiro, Rio de Janeiro, Brasil.

2) Bolsista Produtividade Científica CNPq. 


\section{MATERIAL E MÉTODOS}

O material estudado incluiu 282 exemplares, entre eles cinco holótipos ( $B$. nigricornis, $B$. varicornis, $B$. plumata, $B$. atricornis, $B$. maricaensis $)$, um lectótipo (B. leucoprocta), cinco síntipos (B. annulatd) e 23 parátipos (2 B. varicornis, 2 B. flavicoxa e 19 B. maricaensis). Pertencem as seguintes coleções: The Natural History Museum (BMNH), Londres, Inglaterra; Departamento de Zoologia, Universidade Federal do Paraná (DZUP), Curitiba, Paraná, Brasil; Museu Nacional, Universidade Federal do Rio de Janeiro (MNRJ), Rio de Janeiro, Brasil; United States National Museum (USNM), Washington, D.C., EUA; Zoologisk Museum (ZMUC), Universitets Copenhagen, Copenhagen, Dinamarca e Staatliches Museum für Tierkunde (SMT), Dresden, Alemanha.

Para as descrições foi utilizada a terminologia de MCALPINE (1981). As seguintes abreviaturas aparecem nas sinonímias: (desc.) descrição, (redesc.) redescrição, (cat.) catálogo, (sin.) sinonímia, (ch.) chave, (coment.) comentários, (cit.) citação.

\section{Bithoracochaeta Stein, 1911}

Bithoracochaeta Stein, 1911: 177 (desc.). - Stein, 1919: 157 (cat.). - Stein, 1920: 93. - Malloch, 1921: 106 (sin.). - Curran, 1928: 87. - Curran, 1934: 395 (ch.). - Malloch, 1934: 175, 225 (redesc., coment). - Huckett, 1934: 57, 59, 60-61 (coment., sin.). - Séguy, 1937: 188, 189, 544 (ch., desc., sin., Fig. ). -Albuquerque, 1956, 1-2: (coment., sin., desc.). - Pont, 1972: 36 (cat., sin.). - Carvalho \& Couri, 1992: 36 (cit.). - Couri \& Lopes, 1985: 593 (ch.). - Carvalho et al. 1993 (cat., sin.). Motta \& Couri 1995: 47-53 (desc).

Descrição. Macho: olho nu; dicóptico, margens dos olhos levemente convergentes em direção à lúnula; arista com cílios basais medindo cerca do dobro da largura da arista na base; flagelômero com ápice acuminado; cerdas dorsocentrais $1: 2$; cerdas acrosticais pré-suturais desenvolvidas; cerda pré-alar ausente, notopleura sem cílios de revestimento; cerdas notopleurais longas, de comprimento semelhante entre si; duas cerdas pró-episternais e duas pró-epimerais; espiráculo anterior estreito e alongado; catepímero nú; asas com veias nuas; tíbia posterior com cerdas longas nas faces ântero-ventral, ântero-dorsal e póstero-dorsal, inseridas no terço médio, algumas espécies com uma cerda na face póstero-ventral; primeiro esternito nu. Fêmea: cerda vertical interna longa, dirigida para trás e vertical externa curta dirigida para fora; cerdas interfrontais ausentes; probóscide com arco posterior do fulcro com a ponta desenvolvida maior que o comprimento total, curvatura inferior do fulcro acentuada; haustelo nu, parcialmente esclerotinizado; labelo com dentes prestomais desenvolvidos, palpo com cerdas fortemente esclerotinizadas; ovipositor longo com microtríquias presentes em toda extensão ventral e dorsal; cercos finos e longos; tergitos 6,7 e 8 , em forma de âncora, o tergito 8 mais afilado que os demais, com uma dilatação no ápice; esternitos 6 e 7 em forma de bastão afilado com extremidade posterior dilatada. Espermatecas ovaladas em número de três. 


\section{Chave para as espécies de Bithoracochaeta}

1. Tíbia posterior com três cerdas longas no terço médio, parafaciália não visível de

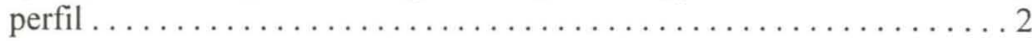

-. Tíbia posterior com quatro cerdas longas no terço médio; parafaciália visível de

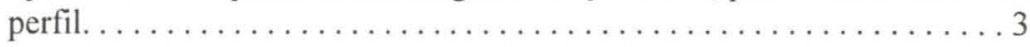

2. Coxa e fêmur anteriores castanho-escuros; cerdas catepisternais como na figura 59 ; ovipositor com tergitos 6, 7 e 8 como na figura 11. [Costa Rica] ...... nigricornis Malloch, 1934

-. Coxa e fêmur anteriores amarelos, este com o ápice levemente castanho; cerdas catepisternais como na figura 57; tergitos 6, 7 e 8 como na figura 5. [Costa Rica, El Salvador, Guiana Inglesa, Brasil] . . . . . . flavicoxa Malloch, 1934

3. Fêmures médio e posterior amarelos com uma faixa castanho-clara; hipândrio tubular curto (Fig. 17); cerdas catepisternais como na figura 62. [Brasil, Argentina $]. . . \ldots \ldots \ldots \ldots \ldots \ldots \ldots$ atricornis Malloch, 1934

-. Fêmures médio e posterior sem faixa castanho-clara; hipândrio tubular longo; cerdas catepisternais dispostas de forma diferente da figura $62 \ldots \ldots \ldots 4$

4. Hipândrio sem espinhos (Fig. 19); fêmur anterior amarelo; cerdas catepisternais como na figura 61. [Estados Unidos da América, México, Cuba, Costa Rica, Panamá, Brasil, Argentina, Paraguai, Uruguai].

leucoprocta (Wiedemann, 1830)

-. Hipândrio com espinhos; cerdas catepisternais dispostas de maneira diferente da

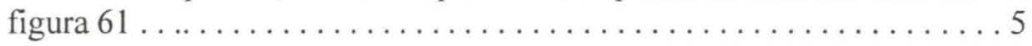

5. Fêmures médio e posterior castanhos. ..................... 6

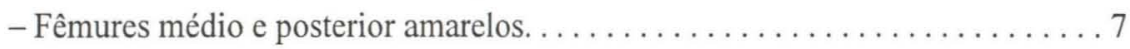

6. Mesonoto com uma listra central bem marcada que atinge o ápice do escutelo; antenas com os 2 primeiros artículos e a extremidade basal do flagelômero castanho-escuros, o resto amarelo; triângulo ocelar com polinosidade dourada; cerdas catepisternais dispostas como na figura 60; placa cercal com borda posterior sem incisão. [Porto Rico, Brasil]. .

varicornis (Coquillett, 1900)

- Mesonoto com listra mediana pouco nítida; antenas castanhas com polinosidade prateada; triângulo ocelar com polinosidade prateada; cerdas catepisternais dispostas como na figura 56; placa cercal com 3 incisões na borda posterior, a mediana um pouco mais profunda (Fig. 30). [Brasil]. .............. .......................... maricaensis Couri \& Motta, 1994

7. Macho com flagelômero castanho com polinosidade cinza; coxa anterior amarela com a parte posterior castanha; arista ciliada em toda a extensão; cerdas catepisternais como na figura 58. [Brasil] .... plumata Albuquerque, 1955

- Macho com flagelômero amarelo; coxa castanha com o ápice amarelo; arista ciliada nos dois terços basais; cerdas catepisternais como na figura 63. [Suriname, Brasil, Peru] . .................. annulata Stein, 1911 


\section{Bithoracochaeta annulata Stein, 1911}

Figs $1,2,21,28,31,38,43,52,63$

Bithoracochaeta annulata Stein, 1911: 178 (desc.). - Stein, 1919: 157 (cat.). - Huckett, 1934: 60 (cit.). -Séguy, 1937: 190, 540 (sin.). - Malloch, 1934:226(ch. variedade de leucoprocta). -Albuquerque, 1956: 2-6 (coment.,sin. desc.). - Pont, 1972: 36 (cat., sin.). - Carvalho et al. 1993 (cat., sin.).

Material-tipo examinado: 3 sintipos fềmea etiquetados: "Typus!" [etiqueta vermelha]; "Peru-150m/5-11-03/Pachitea-Münd." [etiqueta verde]; "Coll. W. Schnuse/1911-3" [etiqueta verde]; "Staatl. Museum für/Tierkunde Dresden". "PeruLaristhal/15-viii-03 [manuscrito]/800-2000 m [2000 riscado]"; "Coll. W. Schnuse/1911-3" [etiqueta verde]; "Staatl. Museum für/Tierkunde Dresden". "Peru-Laristhal/14-8-03 [manuscrito]/2-3000 m"; "Coll. W. Schnuse/1911-3" [etiqueta verde]; "Bithoracochaeta/ annulata/Mal." [etiqueta manuscrita]; "Staatl. Museum für/Tierkunde Dresden".

Sintipo fêmea etiquetado: "Peru-Laristhal/16-8-03 [manuscrito]/800-2000 m [2000 riscado]"; "Bithoracochaeta/annulata/Mal." [etiqueta manuscrita em papel pardo dobrado]; "Staatl. Museum für/Tierkunde Dresden"; "Coll. W. Schnuse/1911-3" [etiqueta verde], (SMT). Em bom estado de conservação.

Diagnose: arista ciliada nos dois terços basais. Triângulo ocelar com polinosidade dourada. Cerdas catepisternais dispostas como na figura 63. Coxas castanhas com o ápice amarelo.Tíbia posterior com quatro cerdas submedianas: ântero-ventral, ântero-dorsal, póstero-dorsal e póstero-ventral. Placa cercal com uma incisão rasa na borda posterior. Esternito 5 com protuberância na base (Fig. 52). Hipândrio tubular, esclerotinizado, com espinhos curtos (Figs 21 e 28).

Coloração. Castanha com polinosidade cinza. Parafrontália, parafaciália e gena castanhas com polinosidade prateada; vita frontal castanho escura; triângulo ocelar com polinosidade dourada. Antena castanho-escura; arista e palpo castanhos. Mesonoto com uma listra castanha mediana, duas listras laterais finas coincidentes com a superfície de cerdas dorsocentrais e duas coincidentes com a superfície de cerdas intralares; pleuras da mesma cor do mesonoto; calíptras brancas; balancim amarelo; asas hialinas levemente acastanhadas; coxas castanhas com polinosidade cinza; fêmur anterior amarelo com a metade basal coberta com polinosidade cinza; fêmures médio e posterior amarelos, tíbias amarelas e tarsos castanho-amarelados. Abdômen castanho com áreas com polinosidade cinza, tergitos 2 a 5 com manchas castanhas.

Redescrição. Fêmea: 3,8mm. Asa: 4,0mm.

Cabeça. Olhos afastados entre si, no nível do ocelo anterior, cerca de 0,36 vezes a largura da cabeça; facetas de tamanho uniforme. Cerdas frontais longas em número de quatro pares. Antenas inseridas no nível da metade dos olhos, terceiro artículo medindo cerca de 1,5 vezes o segundo. Arista ciliada nos dois terços basais. Parafácialia estreita, semelhante a largura da gena no nível inferior do olho. Vibrissa longa e forte; uma cerda supra-vibrissal e uma série de sub-vibrissais.

Tórax. Uma cerda umeral; duas pós-umerais ciliformes; uma pré-sutural longa; duas intralares; uma supralar; duas pós-supralares, a posterior mais longa. Escutelo com dois pares de cerdas basais finos e curtos; e um par de cerdas apicais 


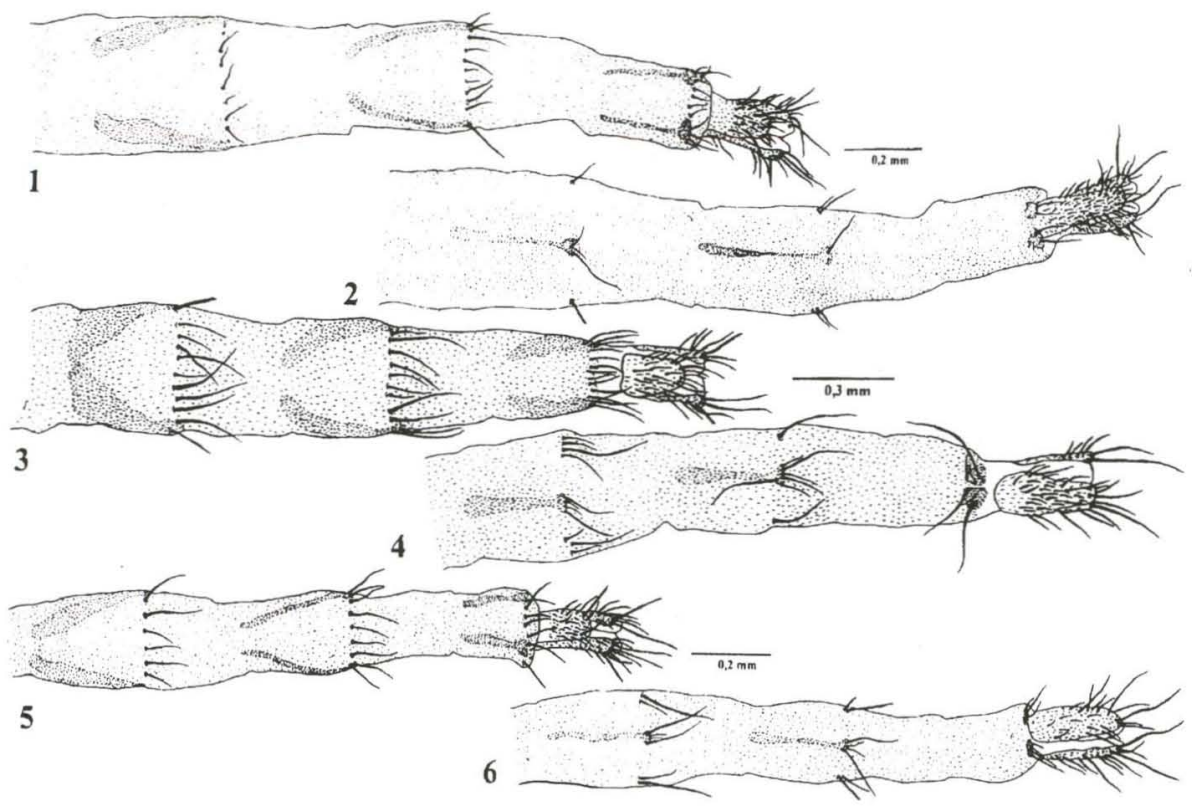

Figs 1-6. Terminália feminina. (1) B. annulata, vista dorsal; (2) B. annulata, vista ventral; (3) B. atricornis, vista dorsal; (4) B. atricornis, vista ventral; (5) B. flavicoxa, vista dorsal; (6) B. flavicoxa, vista ventral.

fortes, cerca de 6 vezes o comprimento do par basal. Fêmur anterior na face dorsal com uma série de cerdas regulares; faces póstero-dorsal, posterior e póstero-ventral com uma série irregular de cerdas; tíbia na face posterior com uma longa cerda supramediana, faces ântero-dorsal e póstero-dorsal com uma cerda inserida no terço apical, faces posterior e ventral com uma cerda pré-apical; pré-tarso longo, pouco menor que a soma do comprimento dos demais tarsômeros. Fêmur médio na face dorsal com cerdas irregulares nos dois terços basais, faces póstero-dorsal e posterior com uma cerda no terço apical, face póstero-ventral com uma série irregular de cerdas longas e curtas; tíbia nas faces anterior e posterior com uma cerda supramediana longa, faces ântero-ventral, ventral, póstero-ventral e póstero-dorsal cada uma com uma cerda pré-apical; tarsos como na perna anterior. Fêmur posterior nas faces ântero-ventral, ântero-dorsal e póstero-ventral com uma série irregular de cerdas, face póstero-dorsal com uma cerda no terço apical, tíbia nas faces ântero-ventral, ântero-dorsal, póstero-dorsal e póstero-ventral com longa cerda no terço médio, face dorsal e ântero-dorsal com uma cerda pré-apical, face ventral com uma cerda apical; tarsos como na perna anterior.

Abdômen. Com cerdas laterais nos tergitos 2 a 5 e discais no tergito 5 . Esternito $5 \mathrm{com}$ margem posterior com forte incisão mediana (Fig. 52).

Terminália (Figs 1,2). Cercos mais longos que o epiprocto e ligeiramente mais longos que o hipoprocto. Tergitos 6 e 7 pouco mais largos na base do que no ápice, tergito 8 afilado com uma dilatação no ápice. Esternitos 6 e 7 em forma de 
bastão afilado, com dilatação no ápice, pouco esclerotinizada; esternito 8 reduzido a duas pequenas placas, apresentando duas cerdas cada um.

Macho: 3,6 mm. Asa: 4,0mm.

Semelhante a fêmea, diferindo no que segue: antenas com o segundo artículo castanho-escuro e ápice amarelado, terceiro artículo amarelo e as cerdas das pernas mais curtas que nas fềmeas

Terminália (Figs 21, 28, 31, 38 e 43). Placa cercal mais longa do que larga, bordas anterior e posterior com uma incisão rasa; surstilos com ápice arredondado. Apódema do edeago, esclerotinizado e longo, envolvido na metade basal pelo hipândrio; hipândrio tubular, esclerotinizado, com espinhos curtos. Parâmeros curtos e alargados com pequenos espinhos.

Material examinado. SURINAME: Mazaruni, 1 fêmea, 27-VIII.1937, Richards e Smart leg. (BMNH); Coronie, 1 macho, 15-III.1945, Gersler leg. (MNRJ). BRASIL, Minas Gerais: Diamantina, 11 machos, 13 fêmeas e 2 exemplares com abdômen danificado, 3-7-III.1956, D. Albuquerque \& Izolda Albuquerque leg. (MNRJ); Rio de Janeiro: Teresópolis, 1 fêmea, 25-I.1940, Lopes leg. (MNRJ). PERU: Foz do rio Pachitea, 1 fềmea, 16-XI.1903, W. Schnuse leg. (SMT); Rio Ucayali, 1 fêmea, 22-X.1903, W. Schnuse leg. (SMT); Vale de Laris, 1 fêmea, 14-VIII.1903, W. Schnuse leg. (SMT); 1 fêmea, 15-VIII.1903, W. Schnuse leg. (SMT); 1 macho, 16-VIII.1903, W. Schnuse leg. (SMT).

Registro geográfico: Guiana Inglesa, Suriname, Brasil (Minas Gerais, Rio de Janeiro), Peru.

\section{Bithoracochaeta atricornis Malloch, 1934}

Figs $3,4,17,24,35,45,55,62$

Bithoracochaeta atricornis Malloch, 1934: 226-228. - Albuquerque, 1956: 6-9 (coment. sin., desc.). Pont, 1972: 36 (cat.). - Carvalho et al. 1993: 113 (cat., sinônimo de leucoprocta). - Motta \& Couri, no prelo (revalidação).

Material tipo examinado: Holótipo macho, etiquetado: "Holo-/type" [etiqueta circular branca com bordo vermelho]; "Bithoracochaeta/ atricornis/Type [manuscrito]/ det. JRMALLOCH" [etiqueta branca com borda preta]; "Viedma./ 23.X.1926.”; "Argentina/Terr. Rio Negro/F\&M. Edwards/B.M. 1927-63" (BMNH). Faltando a cabeça.

Diagnose. Arista ciliada nos dois terços basais. Cerdas catepisternais como na figura 62. Coxas castanhas com polinosidade cinza. Fêmures médio e posterior amarelos com uma faixa castanha no terço médio.Tíbia posterior com quatro cerdas submedianas: ântero-dorsal, póstero-dorsal, póstero-ventral e ântero-ventral. Placa cercal com duas incisões rasas na borda posterior. Apódema do edeago com ápice dilatado. Tergito $6 \mathrm{com}$ base bastante alargada. Tergito 8 não dilatado no ápice.

Coloração. Castanha com polinosidade cinza. Triângulo ocelar com polinosidade dourada. Parafrontália, parafaciália e gena castanhas com polinosidade prateada; vita frontal castanho-enegrecida; antena castanho-escura com polinosidade prateada, mais clara no ápice do segundo artículo, arista castanho-escura; palpo castanho. Mesonoto com uma listra mediana castanha que se estende até a metade 


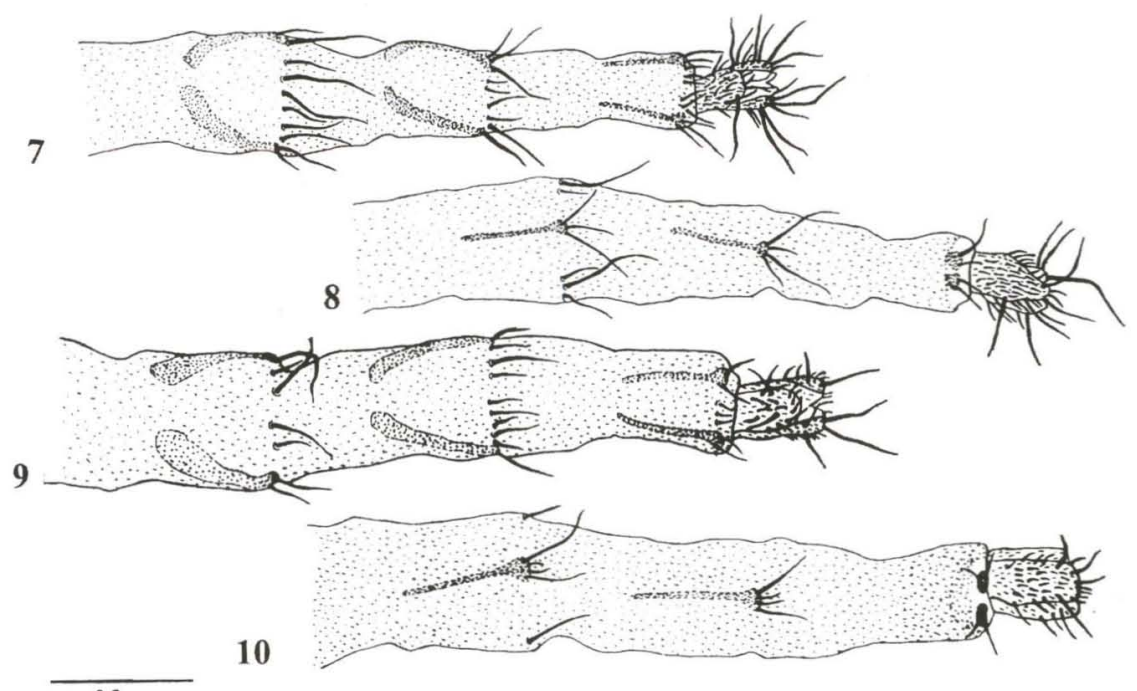

$0,3 \mathrm{~mm}$

Figs 7-10. Terminália feminina. (7) B. leucoprocta, vista dorsal; (8) B. leucoprocta, vista ventral; (9) B. maricaensis, vista dorsal; (10) B. maricaensis, vista ventral.

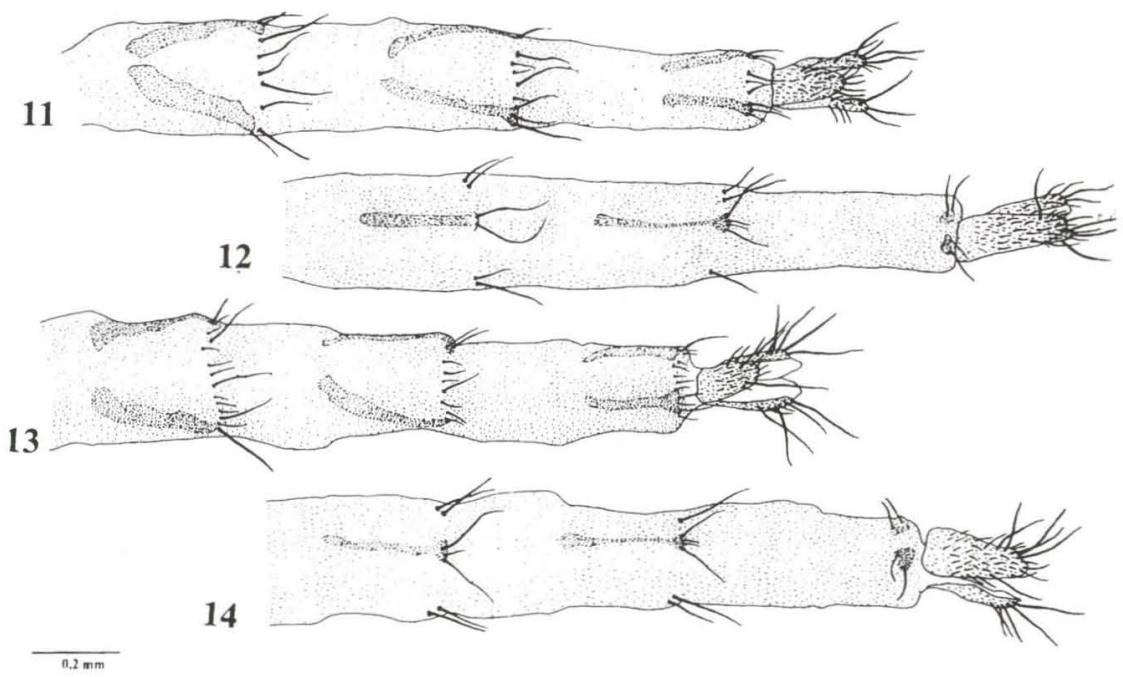

Figs 11-14. Terminália feminina. (11) B. nigricornis, vista dorsal; (12) B. nigricornis, vista ventral; (13) B. varicornis, vista dorsal; (14) B. varicomis, vista ventral.

do escutelo; duas listras laterais coincidentes com a superfície de cerdas dorsocentrais, duas listras laterais mais finas coincidentes com as superficies de cerdas intralares; pleuras da mesma cor do mesonoto; calíptras brancas, balancim amarelo esbranquiçado, asas hialinas. Coxas castanhas com polinosidade cinza, trocânteres amarelos. Fêmur anterior com os dois terços basais castanho-escuros e o terço apical 

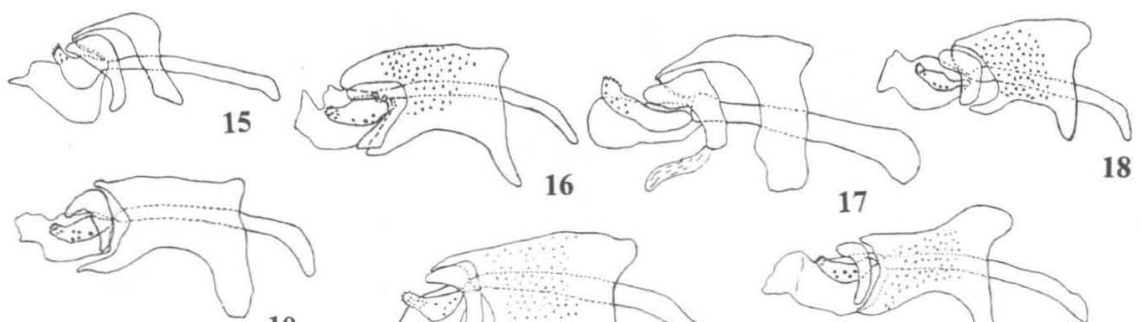

16
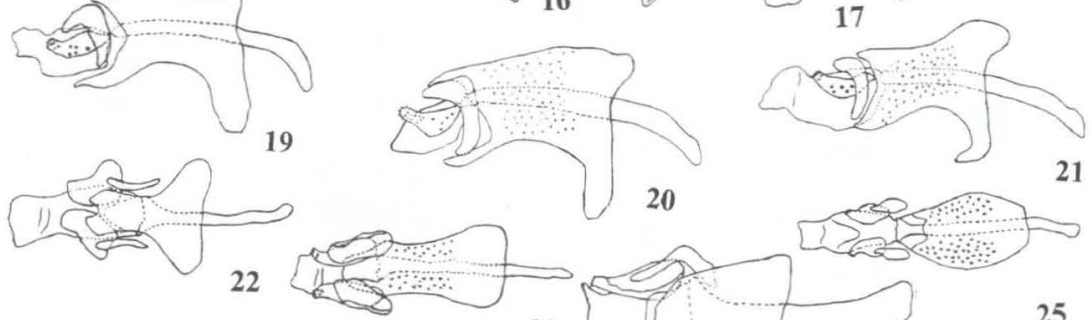

23

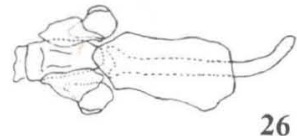

26
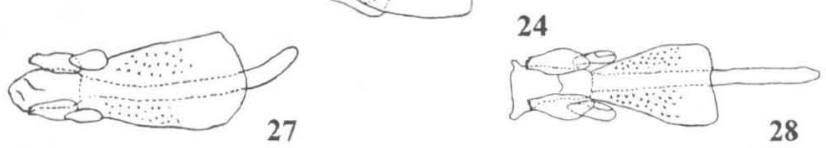

Figs 15-28. Complexo fálico. (15-21) Vista lateral: (15) B. flavicoxa; (16) B. varicornis; (17) B. atricornis; (18) B. maricaensis; (19) B. leucoprocta; (20) B. plumata; (21) B. annulata. (22-28) Vista dorsal: (22) B. flavicoxa; (23) B. varicornis; (24) B. atricornis; (25) B. maricaensis; (26) B. leucoprocta; (27) B. plumata; (28) B. annulata.

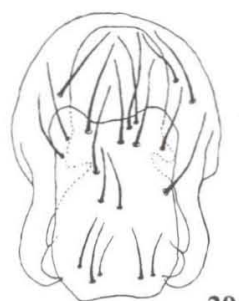

29
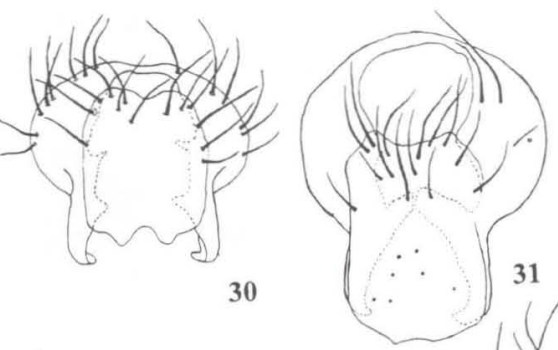

31
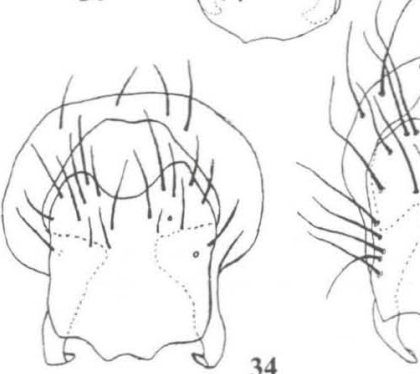

34

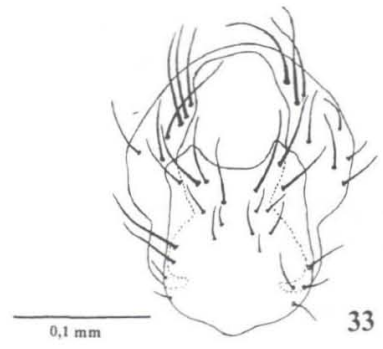

33

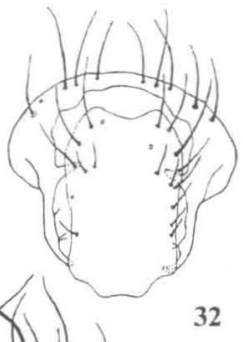

32

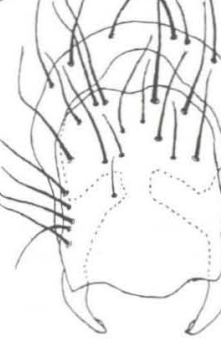

25

28

Figs 29-35. Placa cercal. (29-32) Vista dorsal: (29) B. leucoprocta; (30) B. maricaensis; (31) B. annulata; (32) B. flavicoxa. (33-35) Vista dorsal: (33) B. varicornis; (34) B. plumata; (35) B. atricornis. 


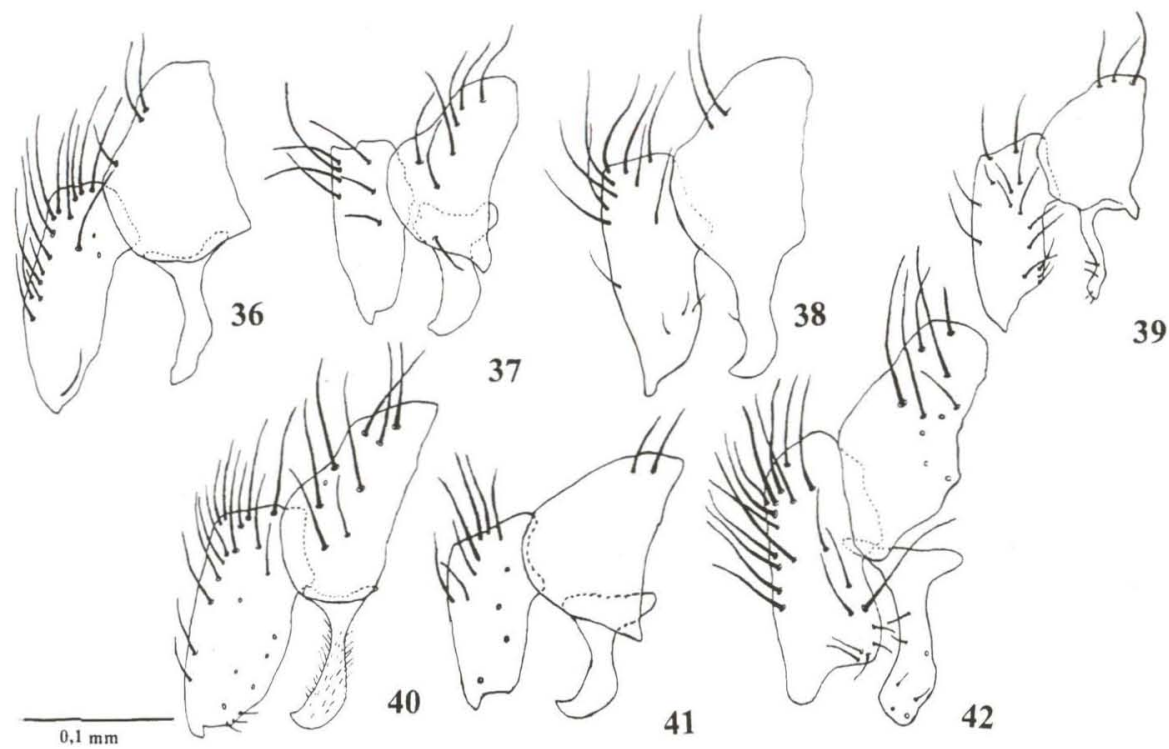

Figs 36-42. Placa cercal, vista lateral. (36) B. leucoprocta; (37) B. maricaensis; (38) B. annulata; (39) B. flavicoxa; (40) B. varicornis; (41) B. plumata; (42) B. atricornis.

amarelo. Fêmur médio e posterior amarelos com um anel castanho claro no limite dos terços médio e apical (alguns exemplares não apresentam o anel), mais intenso nas fêmeas. Tíbias amarelas; tarsos castanhos. Abdômen castanho com polinosidade cinza e com faixa castanho mediana em todos os tergitos, manchas laterais nos tergitos 2 a 4 .

Redescrição. Macho: 3,6mm. Asa: 3,8mm.

Cabeça. Olhos afastados entre si, no nível do ocelo anterior, cerca de 2,8 vezes a largura da cabeça; facetas de tamanho uniforme. Cerdas frontais em número de quatro pares. Antenas inseridas um pouco acima do nível da metade dos olhos, flagelômero medindo cerca de 1,6 vezes o segundo. Arista ciliada com os cílios diminuindo de tamanho em direção ao ápice. Um par de vibrissas, 1-2 cerdas supra-vibrissais e cerca de 2-3 sub-vibrissais.

Tórax. Duas cerdas umerais; uma pós-umeral; uma pré-sutural forte; duas intralares; uma supralar; duas pós-supralares, a posterior maior. Anepisterno com uma fileira de cinco cerdas. Escutelo com um par de cerdas basais, e um par de apicais cerca de quatro vezes o comprimento do par basal. Fêmur anterior na face póstero-dorsal com uma série de cerdas irregulares, face posterior com uma cerda forte no terço basal, face póstero-ventral com uma série irregular de cerdas; tíbia na face posterior com uma longa cerda mediana e duas cerdas na metade apical; faces ântero-dorsal e dorsal com uma cerda inserida no terço apical, faces póstero-dorsal e posterior com 1 cerda pré-apical; pré-tarso pouco menor que a soma do comprimento dos demais tarsômeros. Fêmur médio na face anterior com uma fileira irregular de cerdas nos dois terços basais, face ântero-ventral com uma fileira 
irregular de cerdas; face póstero-ventral com uma fileira irregular de cerdas longas e curtas nos dois terços basais, faces póstero-dorsal e posterior com uma pré apical; tíbia na face anterior com uma cerda longa mediana, face posterior com uma cerda supra-mediana, faces póstero-dorsal e posterior com uma cerda pré-apical, faces póstero-ventral e ântero-ventral com uma cerda apical. Tarso como na perna anterior. Fêmur posterior na face póstero-dorsal com uma série irregular de cerdas, faces póstero-ventral e ântero-ventral nos dois terços basais com uma série irregular de cerdas, face ântero-dorsal com uma série irregular de cerdas no terço apical; tíbia nas faces ântero-ventral, ântero-dorsal, póstero-dorsal e póstero-ventral com longa cerda no terço médio; face dorsal com uma cerda inserida no terço apical, face ventral com uma cerda apical forte, face ântero-dorsal com uma cerda pré-apical; tarso como na perna anterior.

Abdômen. Com cerdas laterais nos tergitos 2 a 5 e discais no tergito 5 . Esternito 5 (Fig. 55) com incisão mediana da margem posterior, medianamente profunda; duas cerdas mais longas próximas a margem posterior.

Terminália (Figs 17, 24, 35, 42 e 45). Placa cercal mais longa do que larga, incisão anterior rasa, borda posterior com duas incisões rasas, surstilos com o ápice arredondado. Apódema do edeago esclerotinizado e longo, dilatado no ápice, envolvido em seu terço mediano pelo hipândrio, alargado na porção dorsal, e esclerotinizado. Parâmeros alongados com pequenos espinhos na metade apical.

Fêmea. 4,1 mm. Asa: 4,0mm.

Semelhante ao macho, com cerdas mais desenvolvidas.

Terminália (Figs 3 e 4). Cercos mais longos que o epiprocto e ligeiramente mais longos que o hipoprocto; tergito 6 alargado na base, tergitos 7 e 8 com a mesma largura em toda a extensão. Esternitos 6 e 7 em forma de bastão, sendo o esternito 7 pouco esclerotinizado em sua metade apical; esternito 8 reduzido a duas pequenas placas sub-triangulares, com tres cerdas cada um.

Material examinado. BrasiL, Minas Gerais: Diamantina, 1 fêmea, 3 a 7-III.1956, D. Albuquerque \& Izolda Albuquerque leg. (MNRJ); Nova Lima(Lagoa Grande), 1 fêmea, 13-II.1978, H.S. Lopes leg. (MNRJ); Rio de Janeiro: Itatiaia (Lago Azul), 1 fêmea, 16-18.1956, Rego Barros e D. Albuquerque leg. (MNRJ). Nova Friburgo, 2 fêmeas, 23-IV.1937, S. Lopes leg. (MNRJ); Petrópolis (Alto da Mosela), 1 fêmea, 6-II.1971, D.O. Albuquerque leg. (MNRJ); Teresópolis, 4 fêmeas, XII.1939, Freitas leg. (MNRJ); 2 fêmeas e 1 exemplar com o abdômen danificado, XI.1939, Freitas leg. (MNRJ); 1 fềmea e 2 exemplares com o abdômen danificado, XI.1940, Freitas leg. (MNRJ); 2 fềmeas, XI.1940, Freitas leg. (MNRJ); Vassouras, 1 fềmea, I.1940, D. Machado leg. (MNRJ); São Paulo: Campos do Jordão, 1 fêmea, 24-IX.1938, N. Santos leg. (MNRJ); Itaquaquecetuba, 1 fêmea, 18-V [sem ano], C.H.T. Townsend leg. (MNRJ); Mogi das Cruzes, 1 fềmea, XI.1939, M. Carrera leg. (MNRJ); São José dos Campos, 5 fêmeas, VII.1933, H.S. Lopes leg. (MNRJ); 2 fêmeas, X.1933, H.S. Lopes leg. (MNRJ); Sumaré, 1 fềmea, I.1942, Carrera leg. (MNRJ). Paraná: Curitiba, 1 fêmea, 17-II.1966, sem coletor (DZUP); Lapa, 1 macho, 5-XII.1981, E.R. Silveira leg. (DZUP); Morretes (Vista Lacerda), 1 fêmea, 17-III.1966, Giacomel e Marinoni leg. (DZUP); Tijucas do Sul, 2 machos e 1 fêmea, 23-24-XI.1979, Claudio Carvalho leg. (DZUP); Santa Cata- 


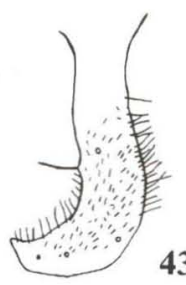

43

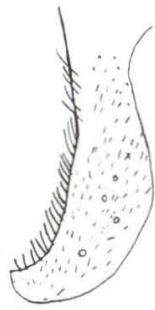

44
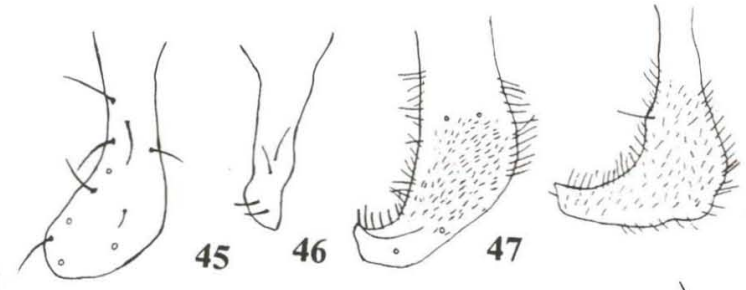

48
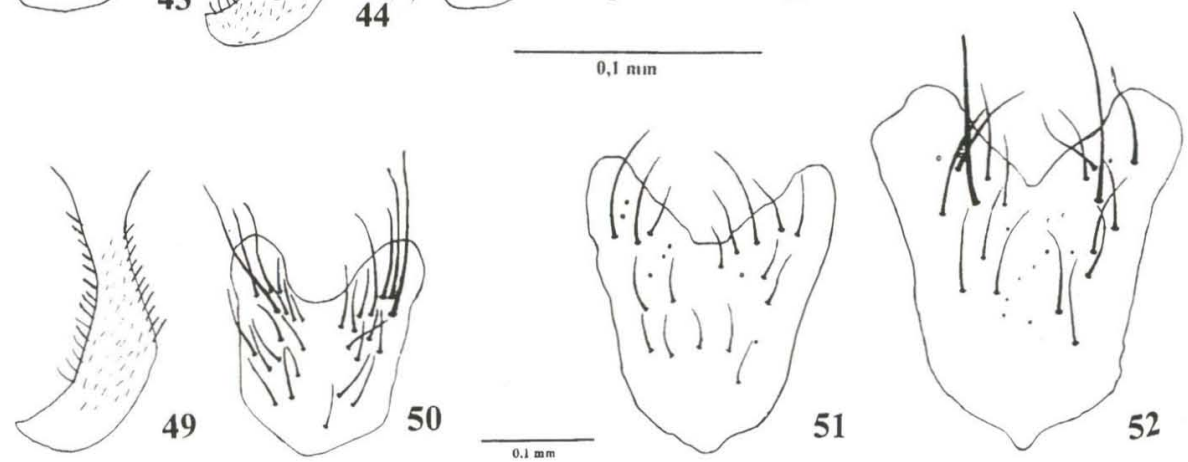

Figs 43-52. (43-49) Surstilo, vista lateral: (43) B. annulata; (44) B. leucoprocta; (45) B. atricornis; (46) B. flavicoxa, (47) B. maricaensis; (48) B. plumata; (49) B. varicornis. (50-52) Esternito V: (50) B. flavicoxa; (51) B. maricaensis; (52) B. annulata.

rina: Seara (Nova Teutônia), 1 fêmea, 30-XII.1934, Fritz Plaumann leg. (BMNH); 1 fêmea, 4-XI.1935; 1 fêmea, 5-XI.1935; 1 macho, 5-XI.1936; 1 fềmea, 9-XI.1936; 1 macho, 5-XII.1936; 1 macho, 9-VI.1937; 1 fêmea, 15-VI.1937; 1 macho, 2VII.1937; 1 fêmea, 7-VII.1937; 1 exemplar com o abdômen danificado, 10VI.1938. ARgentina, Buenos Aires: Buenos Aires (inst. Jose C. Paz), 1 macho e 2 fêmeas, 24-VIII.1939, Ogloblin leg. (MNRJ); 1 macho e 1 fềmea, 25-VIII.1939, Ogloblin leg. (MNRJ); 4 fềmeas, 2-X.1939, Ogloblin leg. (MNRJ); 3 fềmeas, 10-IX.1939, Ogloblin leg. (MNRJ); (Vila del Parque), 1 fêmea e 1 exemplar com o abdômen danificado, 13-VIII.1937, Ogloblin leg. (MNRJ). Rio Negro, 1 macho, 23-X.1926, F\&M. Edwards leg. (BMNH).

Registro geográfico: Brasil (Rio de Janeiro, Minas Gerais, São Paulo, Paraná, Santa Catarina), Argentina.

\section{Bithoracochaeta flavicoxa Malloch, 1934}

Figs $5,6,15,22,32,46,50,57$

Bithoracochaeta flavicoxa Malloch, 1934: 175, 226, 228: (ch., desc.).- Albuquerque, 1956 (sin.). -Pont, 1972: 36 (cat., sin.). - Carvalho \& Couri, 1992: 36. - Carvalho et al. 1993: 112 (cat.).

Material tipo examinado. Parátipo macho, etiquetado: "/Para./type" [etiqueta circular branca com borda amarela]; Bithracochaeta/flavicoxa/Paratype [manuscrito] /det. JRMALLOCH" [etiqueta branca com borda preta]; "Farm. La Caja./8km. wetl.S.José/15.4.-20.6.1924." [etiqueta verde]; "Costa Rica./Eing. Nr.59.1925" [etiqueta verde], ZSZMH. Em dupla montagem, em bom estado geral, faltando tíbia da perna mediana direita, tarsômeros das pernas posteriores, terminália em tubinho de vidro. 

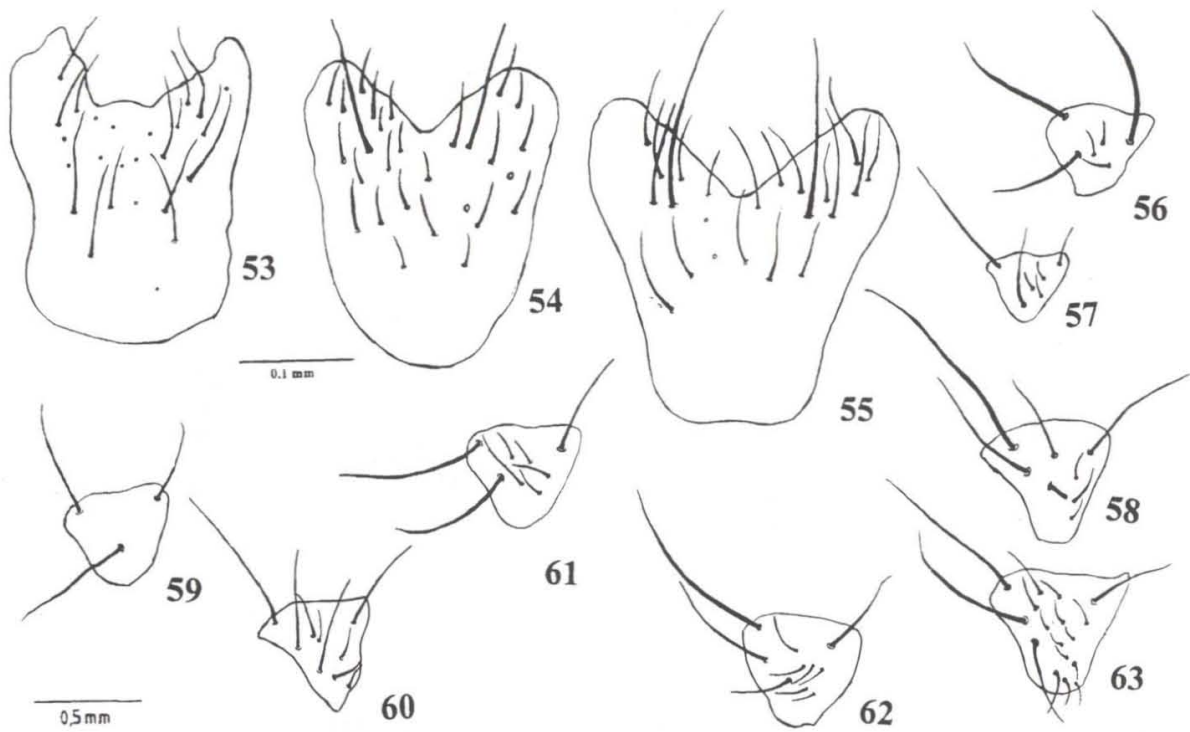

60

62

Figs 53-63. (53-55) Esternito V: (53) B. leucoprocta; (54) B. plumata; (55) B. atricornis. (56-63) Cerdas do catepisterno: (56) B. maricaensis; (57) B. flavicoxa; (58) B. plumata; (59) B. nigricornis; (60) B. varicornis; (61) B. leucoprocta; (62) B. atricornis; (63) B. annulata.

Parátipo fêmea, etiquetado: "/Para./type" [etiqueta circular branca com borda amarela]; "Farm La Caja./8km.wetl.S.José./15.4.-20.6.1924." [etiqueta verde]; "Costa Rica./Eing. Nr.59.1925" [etiqueta verde], (BMNH). Dupla montagem, em bom estado de conservação, coloração levemente alterada.

Diagnose. Genas quase imperceptíveis. Arista totalmente ciliada. Cerdas catepisternais como na figura 57. Calíptra inferior linguiforme. Coxa anterior amarela. Tíbia posterior com três cerdas submedianas: ântero-ventral, ântero-dorsal, póstero-dorsal. Surstilo muito afilado. Hipândrio em forma de anel; tergitos 6, $7 \mathrm{e}$ 8 como na figura 15 .

Coloração. Castanho-escura com polinosidade castanha. Parafrontália, parafaciália e gena castanhas com polinosidade prateada. Antena castanho-escura, segundo artículo castanho-amarelado no ápice; arista castanho-escura; palpo castanho. Mesonoto sem listras; pleuras com polinosidade cinza; caliptra branca, balancim amarelo. Asa castanho hialina. Pernas amarelas, tarsos castanhos, pulvilos esbranquiçados e unhas negras. Abdômen castanho escuro brilhoso com polinosidade prateada formando manchas laterais nos tergitos 3 a 5 .

\section{Redescrição. Macho: 3,4mm. Asa: 3,6mm.}

Cabeça. Olhos afastados entre si no nível do ocelo anterior cerca de 0,40 vezes a largura da cabeça, facetas de tamanho uniforme. Cerdas frontais em número de quatro pares. Antenas inseridas acima da metade dos olhos, flagelômero medindo cerca de 2,0 vezes o segundo. Gena quase imperceptível. Vibrissa longa, uma cerda supravibrissal. 
Tórax. Duas cerdas umerais; uma pós-umeral; uma pré-sutural; duas intralares; uma supralar; uma pós-supralar. Anepisterno com uma fileira de cinco cerdas. Escutelo com dois pares de cerdas basais, laterais finos e fracos, um par abaixo deste cerca de quatro vezes o comprimento do primeiro, e um par de cerdas apicais (quebradas). Fêmur anterior na face dorsal com uma série irregular de cerdas, face póstero-dorsal no terço basal com duas cerdas, face póstero-ventral com cinco cerdas longas e espaçadas; tíbias na face posterior com longa cerda mediana, faces dorsal e póstero-dorsal com uma cerda pré-apical, face póstero-ventral com uma cerda apical longa. Pré-tarso pouco menor que a soma do comprimento dos demais tarsômeros. Fêmur médio nas faces póstero-dorsal e posterior com uma cerda pré-apical, face póstero-ventral com cerca de seis cerdas longas; tíbia na face anterior, mediana e posterior com uma cerda supra-mediana longa, face pósterodorsal, póstero-ventral, ventral e ântero-ventral cada uma com uma cerda pré-apical, sendo as três últimas mais desenvolvidas, tarsos, unhas e pulvilos como na perna anterior. Fêmur posterior na face póstero-dorsal com uma cerda pré-apical, face póstero-ventral com uma série irregular de cerdas, sendo a do terço apical mais longa, face ântero-ventral com uma série irregular de cerdas terminada por uma mais longa, face ântero-dorsal com uma série irregular de cerdas. Tíbia nas faces ântero-ventral, ântero-dorsal e póstero-dorsal com longa cerda no terço médio. Faces dorsal e ântero-dorsal com uma cerda pré-apical, face ventral com uma cerda apical forte; tarsos, unhas e pulvilos como na perna anterior.

Abdômen. Tergito 2 com um par de cerdas laterais longas, tergito 4 e cinco com cerdas discais. Esternito 5 com margem posterior com forte incisão mediana.

Terminália (dissecado o parátipo, Figs 15, 22,32,39 e 46): placa cercal pouco mais longa do que larga, borda anterior com uma incisão anterior rasa, borda posterior com duas. Surstilos afilados com o ápice ponteagudo. Apódema do edeago esclerotinizado e longo, circundado no terço basal pelo hipândrio que forma um anel mais alargado dorsalmente. Parâmeros curtos e alargados com poucos espinhos apicais.

Fêmea. 3,6mm. Asa:3,7mm.

Semelhante ao macho, diferindo no que se segue: palpo castanho escuro; coxas; tarsos; fêmures e tíbias castanho-claros e tarsos castanho-escuros. Abdome castanho-escuro brilhoso com polinosidade prateada e com uma faixa nos tergito 2 -4 , tergito 5 com uma faixa castanha. Quetotaxia mais desenvolvida que nos machos.

Terminália (dissecado o parátipo, Figs 5 e 6): cercos mais longos que o epiprocto e ligeiramente mais longos que o hipoprocto; tergito 6, ligeiramente alargado na base, tergito 7 longo e bastante afilado, tergito 8 de largura uniforme. Esternito 6 e 7 longos com uma dilatação no ápice pouco esclerotinizada, esternito 8 reduzido a duas pequenas placas sub-triangulares com três cerdas cada um.

Material examinado. El SAlvador: La Libertad, S. Tecla, 1 fêmea e 1 exemplar com o abdômen danificado, 18-XII.1953, M. Salazar (USNM). CosTA RicA: San José (Fazenda La Caja), 1 macho, 15-IV-20-VI.1924, sem coletor, (BMNH); 1 fềmea, 15-IV-20-VI.1924, sem coletor, (BMNH); 1 fêmea, sem data, J.F. Tristán leg. (USNM). GuIANA INGLESA: Mazaruni, 1 fêmea, 13-VIII.1937, 
Richards \& Smart leg. (BMNH). Sem localidade, 1 fêmea, 20-VIII.1929, sem coletor (BMNH). BRASIL, Roraima: Ilha de Maracá (Rio Urarioera), 2 machos e 4 fêmeas, 19-24-VII.1987, J.A. Rafael e L.S. Aquino leg. (DZUP). $\mathrm{ma})$.

Registro geográfico. El Salvador, Costa Rica, Guiana Inglesa, Brasil (Rorai-

\section{Bithoracochaeta leucoprocta (Wiedemann, 1830)}

Figs $7,8,19,26,29,36,44,53,61$

Anthonyia leucoprocta Wiedemann, 1830: 433 (desc.).

Anthomyia despecta Walker, 1853: 364 (desc.). - Townsend, 1892: 40. - Stein, 1901: 194 (coment.). Huckett, 1934: 60 (cit.).

Coenosia antica Walker, 1853; 367 (desc.). -Stein, 1901: 186 (coment.). -Stein, 1904: 483. - Gowdey, 1926: 85 .

Coenosia pipunculina Thomson, 1869: 559 (desc.). - Stein, 1910: 76 (sin.). - Stein, 1911: 178 (cat.).

Limnophora rufipes Bigot, 1885: 272 (desc.). - Stein, 1910 (sin.). - Malloch, 1921: (sin.).

Hydrophoria calopus Bigot, 1885: 275 (desc.). - Stein, 1910 (sin.). - Malloch, 1921 (sin.).

Coenosia uvens Giglio-Tos, 1894: 11 (desc.). - Séguy, 1937: 216, 219 (cat).

Coenosia femoralis Wulp, 1896: 345 (desc.). - Stein, 1919: 159 (cat.).

Coenosia insignis Stein, 1898: 257 (desc.). - Stein, 1904: 483 (ch., coment.).

Caricea insignis Stein, 1898: 257 (desc.).

Coenosia despecta; Stein, 1910: 76 (coment.).

Bithoracochaeta despecta; Stein, 1911: 177 (desc. Tipo). - Wolcott, 1924: 227. - Wolcott, 1936: 369. - Wolcott 1948: 496.

Bithoracochaeta leucoprocta; Stein, 1919: 157, 170 (cat.). - Stein, 1920: 93. - Malloch, 1921: 44, 107 (sin.). - Curran, 1928: 87. -Engel, 1931: 137 (cit.). - Malloch, 1934: 175, 225, 226-227, 228 (ch., sin., desc.). - Curran, 1934: 469. - Hucket, 1934: 61 (sin.,coment.). - Wolcott, 1936: 369. Blanchard, 1937: 43. - Séguy, 1937: 190, 565. - Wolcott, 1948: 496. - Albuquerque, 1956: 9 (sin.). - Garcia, 1964: sem página. - Huckett, 1965: 874. - Pont, 1972: 36-37 (cat., sin.). - Carvalho et al. 1993: 112 (cat.).

Material-tipo examinado: lectótipo fêmea [des. Pont, MSa. in CARVALHO et al. 1993], etiquetado: "Anthomyia/leucoproctal W./Amer.ins." [manuscrito]; "Type"[etiqueta vermelha]. (ZMUC). Faltam perna média esquerda, perna posterior direita, tíbia e tarso da perna média direita.

Diagnose: arista ciliada nos dois terços basais. Cerdas catepisternais dispostas como na figura 61. Tíbia posterior com quatro cerdas submedianas: ântero-ventral, ântero-dorsal, póstero-dorsal, póstero-ventral. Esternito 5 (Fig. 53) com forma quadrangular. Hipândrio (Figs 19, 26) tubular, esclerotinizado, sem espinhos.

Coloração. Castanho com polinosidade cinza. Parafrontália com polinosidade dourada, parafaciália e gena castanhas com polinosidade prateada; vita frontal castanho escura; triângulo ocelar com polinosidade dourada. Antena com o segundo artículo castanho, luminoso no ápice; flagelômero com o terço basal castanho escuro e os dois terços apicais castanho amarelados; arista castanho-escura, palpo castanho. Mesonoto com uma listra castanho mediana que atinge a metade do escutelo, duas listras laterais finas coincidentes com a superfície de cerdas dorso-centrais cerdas dorsocentrais e duas mais largas coincidentes com a superfície de cerdas intra-lares; pleuras da mesma cor do mesonoto; calíptra branca; balancin amarelo claro; asa 
levemente acastanhada; coxas amarelas; fêmures amarelos, extremo ápice dos fêmures médio e posterior castanhos, tíbias amarelas e tarsos castanho-amarelados. Abdômen castanho com áreas polinosas na metade basal dos tergitos 3-5.

Redescrição. Fêmea: 5,0mm. Asa:4,0mm

Cabeça. Olhos afastados entre si no nível do ocelo anterior por um espaço cerca de 0,34 vezes a largura da cabeça; facetas de tamanho uniforme. Cerdas frontais longas e fortes em número de quatro pares. Antenas inseridas aproximadamente no nível da metade dos olhos, flagelômero medindo cerca do dobro do comprimento do segundo. Parafácialia estreita, semelhante a largura da gena no nível inferior do olho. Vibrissa longa e forte; uma cerda supravibrissal e uma série de subvibrissais.

Tórax. Uma cerda umeral; uma pós-umeral; uma pré-sutural longa; duas intralares; uma supralar; duas pós-supralares. Escutelo com um par de cerdas basais, lateral, fino e curto, um par abaixo deste um pouco mais desenvolvido; e um par de cerdas apicais fortes, cerca de três vezes o comprimento da anterior. Fêmur anterior na face dorsal com seis cerdas, face póstero-ventral com uma série de cerdas longas intercaladas de cerdas curtas; tíbia na face posterior com uma longa cerda supramediana, faces ântero-dorsal e póstero-dorsal com uma cerda inserida no terço apical, faces posterior e ventral com uma cerda pré-apical; pré-tarso longo, pouco menor que a soma do comprimento dos demais tarsômeros. Fêmur médio com três cerdas longas no terço médio da face póstero-ventral, face anterior com duas cerdas no terço médio, face posterior e póstero-dorsal com uma cerda no terço apical. Fêmur posterior com a face póstero-ventral com uma série de cerdas longas e curtas nos dois terços basais, face póstero-dorsal com uma cerda no terço apical, face ânterodorsal e ântero-ventral com uma série irregular de cerdas; tíbia nas faces ânteroventral, ântero-dorsal, póstero-dorsal e póstero-ventral com longa cerda no terço médio, face dorsal e ântero-dorsal com uma cerda pré-apical, face ventral com uma cerda apical; tarsos como na perna anterior.

Abdômen com cerdas laterais nos tergitos 2 a 5 e discais no tergito 5 .

Terminália (Figs 7 e 8). Cercos mais longos que o epiprocto e do mesmo tamanho do hipoprocto; tergito 6 e 7 em forma de ancora, tergito 8 em forma de bastão afilado com ápice dilatado. Esternito 6 e 7 em forma de bastão afilado com dilatação no ápice, esternito 8 reduzido a duas pequenas placas, apresentando duas cerdas cada um.

Macho. 4,2mm. Asa: 4,0mm.

Semelhante a fêmea, diferindo no que segue: esternito 5 com a margem posterior com forte incisão mediana (Fig. 53). Placa cercal ligeiramente mais longa do que larga, incisão anterior rasa, borda posterior reta sem nenhuma reentrância (Fig. 35). Surstilos com o ápice ponteagudo (Fig. 43). Apódema do edeago esclerotinizado e longo, envolvido em sua metade basal pelo hipândrio tubular esclerotinizado; gonópodos curtos e alargados com espinhos (Figs 19, 26).

Material examinado. E.U.A., Carolina do Norte: Southport, 1 macho, 10X.1948, C.W. Sabrosky leg. (USNM); Georgia: Okefenokee Swanp (Billy' Island), 2 machos, 1 fêmea e 1 de sexo não identificado, 15-VI.1912 (sem coletor) (USNM); Tifton, 1 fêmea, 30-VIII.1896, A. L. Melander leg. (USNM); 2 fêmeas, 17-X.1896. 
A.L. Melander leg.(USNM); Mississipi: Pass Christian, 1 macho e 1 fêmea, 7VI.1917, J.M. Aldrich leg. (USNM); 1 fêmea, 8-VI.1917, J.M. Aldrich leg. (USNM); Texas: Galveston, 2 machos, 2 fêmeas e 1 de sexo não identificado, (sem data e coletor) (USNM); Louisiana: Lake Charles, 2 fềmeas, 9-VI.1917, J.M. Aldrich leg. (USNM); New Orleans, 1 macho, 29-III.1905, Jas S. Hine leg. (USNM); Opelousas, 2 macho e 1 fêmea, IV.1897, J.M. Aldrich leg. (USNM); 3 machos, V.1917, J.M. Aldrich leg. (USNM); Florida: Alachua, 1 fềmea, 29XI.1953, F.W. Mead leg. (USNM); 1 fêmea, 29-I.1954, H.V. Weems Jr. leg. (USNM); Bisc. Bay, 1 macho, Slosson leg. (USNM); CH. Her, 1 fêmea (sem data e coletor) (USNM); De Soto (Arcadia), 2 machos e 1 fêmea, 1-IV.1972, Miller e Kurczewski leg. (USNM); Diaytim, 1 macho, 3-IX.1894(USNM); Fort Lauderdale, 2 fêmeas, 5-II.1950, O. Link leg. (USNM); Highlands Hamm St., 1 macho, 20III.1954, H.V. Weems Jr. leg. (USNM); Hialeah, 1 macho e 1 fêmea, 19-II.1967, C. Stegmaier leg. (USNM); Homesteaf, 1 fêmea, 18-II.1941, L.L. Pechuman leg. (USNM); Key West, 1 macho, 1-II.1969 (USNM); Lakeland, 1 macho e 3 fêmeas, 6-V.1916, J.C. Bradley (USNM); Orlando, 1 macho e 1 fêmea, 14-II.1918 (USNM); Royal Palm Park, 1 fêmea, 22-IV.1930, A.L. Melander leg. (USNM); Sarasota, 1 de sexo não identificado, 21-II.1946, J.G. Needham leg. (USNM); Sebring, 1 macho, 20-III.1950, H.V. Weems Jr. leg. (USNM); St. Augustine, 1 fêmea e 1 macho, 18-IV.1919 (USNM); Terra Ceia, 1 fềmea, 24-II.1946, J.G. Needham leg. (USNM). MÉXICO: Durango, 2 macho e 1 fêmea, XI.1927, F.C. Bishopp leg. (USNM); Orizaba, 1 macho, 1 fêmea e 1 de sexo não identificado, 9-16-I.1892, H. Osborn leg. (USNM). CUBA: Cayanas, 1 fêmea, sem data, Baker leg. (USNM); Havana, 1 macho e 3 fềmeas, sem data, Baker leg. (USNM). CosTA RICA: San José, 1 de sexo não identificado, sem data, H. Sschmidt leg. (USNM). PANAMÁ: Canal Zone, Corazal, 1 fêmea, 1-III.1972, Aug. Busk leg. (USNM). BrasIL, Santa Catarina: Seara (Nova Teutônia), 1 macho, 16-VI.1937, 1 fềmea, 2-XI.1952, Fritz Plaumann leg. (BMNH); Rio Grande do Sul: Quaraí, 1 macho, 21-XI.1985, J.R. Yure leg. (DZUP). ARGENTINA, Buenos Aires: Buenos Aires, 3 fềmeas, 21-X.1926, F\&M Edwards (BMNH); PARAGUAI. Misiones, Sapucay, 1 fêmea, Fevereiro (sem ano de coleta), W.T. Foster leg. (USNM); URUGUAI, Montevideo: 1 macho, 21-22I.1927, F\&M Edwards leg. (BMNH).

Registro geográfico. E.U.A., México, Cuba, Costa Rica, Panamá, Brasil (Santa Catarina, Rio Grande do Sul), Argentina, Paraguai, Uruguai.

\section{Bithoracochaeta maricaensis Couri \& Motta, 1994}

Figs $9,10,18,25,30,47,51,56$

Bithoracochaeta maricaensis Couri \& Motta, 1994: 211-214 (desc.).

Material tipo examinado. Holótipo macho, etiquetado: "Maricá-E. do Rio/22 e 23 -3-1957/D. Albuquerque"; "MNRJ"; "Holotipo" [etiqueta vermelha com uma linha preta no bordo], (MNRJ). Em bom estado, abdômen dissecado, acondicionado em tubinho com glicerina.

Parátipos: 7 machos e 12 fêmeas, etiquetados: "Maricá-E. do Rio/22 e 23 -3-1957/D. Albuquerque"; "MNRJ"; "Paratypo" (etiqueta verde com uma linha preta no bordo) (MNRJ). Em bom estado de conservação. 
Diagnose. Arista ciliada nos dois terços basais. Cerdas catepisternais dispostas como na figura 56. Tíbia posterior com quatro cerdas submedianas: ântero-ventral, ântero-dorsal, póstero-dorsal, póstero-ventral. Placa cercal (Figs 30 e 37) com forte concavidade na membrana posterior. Hipândrio (Figs 18 e 25) com espinhos curtos; terceiro artículo antenal e triângulo ocelar castanhos com polinosidade prateada; mesonoto com listras pouco evidentes.

Coloração. Castanha com polinosidade cinza. Cabeça com parafrontália, parafaciália, gena e triângulo ocelar com polinosidade prateada; vita frontal castanho-enegrecida com polinosidade prateada no centro; antenas castanhas com polinosidade prateada, aristas castanhas; palpo castanho claro. Mesonoto com uma listra castanha mediana pouco evidente e listras laterais finas coincidentes com as superfícies de cerdas dorsocentrais e intralares, menos evidentes que a mediana; pleuras da mesma cor do mesonoto; caliptras brancas, balancim amarelo; asas hialinas; coxas castanho-escuras, trocânteres castanho-escuros dorsalmente e castanho-amarelados ventralmente; fêmures castanho-escuros com o extremo ápice castanho amarelado; tíbias e tarsos castanho-amarelados. Pulvilos esbranquiçados e unhas negras. Abdômen castanho com polinosidade cinza, tergitos com manchas castanhas laterais pouco nítidas.

Redescrição. Macho. 4.1-4.6 mm. Asa:3,6-4.1 mm.

Cabeça. Olhos afastados no nível do ocelo anterior, cerca de 0,4 vezes da largura da cabeça, facetas de tamanho uniforme. Cerdas frontais longas e fortes, em número de quatro pares. Cerdas ocelares fortes, longas e divergentes. Cerdas verticais internas longas, fortes, convergentes e retrovertidas. Cerdas verticais externas pequenas e divergentes. Cerdas pós-verticais finas e convergentes. Cerdas pós-oculares, pouco menores que as cerdas verticais externas. Antenas inseridas aproximadamente no nível da metade dos olhos, terceiro artículo medindo cerca 1,9 vezes o segundo, arista ciliada nos dois terços basais, parafaciália estreita semelhante a largura da gena no nível inferior do olho. Vibrissa longa e forte com uma cerda supravibrissal e duas cerdas subvibrissais.

Tórax. Cerdas acrosticais ciliformes; duas cerdas umerais; uma pós-umeral, uma pré-sutural; uma intralar; uma supralar e duas pós-supralar. Anepisterno com fileira de quatro cerdas, a primeira e a terceira curtas, e a segunda e quarta longas. Escutelo com um par de cerdas basais, laterais, finas e curtas; um par abaixo desse com cerca do dobro do comprimento do primeiro; e um par de cerdas apicais longas e fortes cerca de três vezes o comprimento do anterior. Catepisternais como na figura 56. Fêmur anterior nas faces póstero-dorsal e póstero-ventral com uma série irregular de cerdas; tíbia na face posterior com uma longa cerda mediana, faces dorsal, ântero-dorsal, posterior e póstero-dorsal com uma cerda pré-apical a última mais longa; pré-tarso pouco menor que a soma dos demais tarsômeros, unhas e pulvilos bem desenvolvidos. Fêmur médio com face póstero-ventral com 4 cerdas longas na metade basal; face ântero-ventral com uma série irregular de cerdas; face anterior com duas cerdas no terço médio; tíbias nas faces anterior e posterior com uma cerda mediana longa e forte; faces ântero-dorsal e ântero-ventral com uma cerda apical e face póstero-dorsal com uma cerda pré-apical; tarsos, unhas e pulvilos como na perna anterior. Fêmur posterior nas faces ântero-dorsal, póstero-ventral e ânte- 
ro-ventral com uma série irregular de cerdas; tíbias nas faces ântero-dorsal, ânteroventral, póstero-dorsal e póstero-ventral com longa cerda no terço mediano, faces ântero-dorsal e póstero-dorsal com uma cerda pré-apical, face ventral com cerda apical; tarsos, unhas e pulvilos como na perna anterior.

Abdômen. Cerdas laterais nos tergitos $2 \mathrm{a} 4 \mathrm{e}$ discais no tergito 5. Esternito 5 com margem posterior com forte incisão mediana.

Terminália (dissecado o holótipo, Figs 18, 25, 30, 37, 51, 47). Placa cercal ligeiramente mais longa do que larga, incisão anterior rasa, borda posterior com três incisões rasas, a mediana um pouco mais profunda, surstilos com o ápice arredondado. Apódema do aedeagus esclerotinizado e longo, envolvido em sua metade basal pelo hipândrio tubular, esclerotinizado com curtos espinhos e cerdas.

Fêmea: 5,2 mm. asa:4,2mm.

Semelhante ao macho, com cerdas mais desenvolvidas.

Terminália (dissecado o paratipo, Figs 9 e 10): cercos mais longos que o epiprocto e do mesmo tamanho do hipoprocto; tergitos 6, 7 e 8, com forma de bastão, os tergitos 8 mais afilados que os demais com uma dilatação no ápice. Esternitos 6 e 7 em forma de bastão afilado com extremidade posterior dilatada ; esternito 8 reduzido a duas pequenas placas, apresentando 2 cerdas cada um.

Material examinado. BRASIL, Rio de Janeiro: Maricá (Restinga), 8 machos e 12 fềmeas, 22 e 23-III.1957, D. Albuquerque leg. (MNRJ).

Registro geográfico. Brasil (Rio de Janeiro).

\section{Bithoracochaeta nigricornis Malloch, 1934}

Figs $11,12,59$

Bithoracochaeta nigricornis Malloch, 1934: 175, 226, 228 (ch., desc.). - Albuquerque, 1956: 10 (sin.). - Pont, 1972: 37 (cat., sin.). - Carvalho et al. 1993: 113 (cat.).

Material-tipo. Holótipo fềmea, etiquetado: "Higuito/SanMateo CR"; "Pablo Schild/Coll."; "Type No./USNM"[etiqueta vermelha]; "Bithoracochaeta nigricornis/Type/Det./J.R.Malloch" [manuscrito]. (USNM). Faltam tarso da perna anterior direita, perna média direita; asa esquerda danificada no terço apical.

Diagnose. Genas quase imperceptíveis. Arista ciliada em toda sua extensão. Cerdas catepisternais dispostas como na figura 59. Calíptra inferior linguiforme. Tíbia posterior com três cerdas submedianas: ântero-ventral, ântero-dorsal e póstero-dorsal; hipândrio tubular, esclerotinizado, com espinhos curtos. Tergito 8 (Fig. 11) não dilatado no ápice. Coxa anterior castanho-escura.

Coloração. Castanho escura com polinosidade castanha. Parafrontália castanha, gena castanha coberta com polinosidade cinza. Antena castanho-escura, segundo artículo com brilho intenso no ápice, arista castanho escuro um pouco mais clara na base, palpo castanho escuro. Mesonoto sem listra; pleuras com polinosidade cinza; calíptra branca; balancim amarelo claro; asas levemente acastanhadas; coxa anterior com polinosidade cinza, coxa média e posterior castanho-amareladas; fêmur anterior castanho escuro com o extremo ápice amarelo, fềmur médio e posterior amarelos com o terço ápical castanho escuro, tíbias e tarsos castanhos; 
pulvilos esbranquiçados, unhas negras. Abdômen castanho-escuro brilhoso com pouca polinosidade castanha na metade superior de cada tergito.

Redescrição. Fêmea: 3,8mm. Asa:4,2mm

Cabeça. Olhos afastados entre si ao nível do ocelo anterior cerca de 0,40 vezes a largura da cabeça; facetas de tamanho uniforme. Cerdas frontais em número de quatro. Antena inserida um pouco acima do nível da metade dos olhos, flagelômero medindo cerca de 2,5 vezes o segundo. Gena quase imperceptível. Vibrissa longa; uma cerda supra vibrissal.

Tórax. Duas cerdas umerais; uma pós-umeral; uma pré-sutural; duas intralares; uma supralar; uma pós-supralar. Escutelo com dois pares de cerdas basais, laterais, finos e fracos; e um par de cerdas apicais fortes, cerca de 2 vezes o comprimento das basais. Fêmur anterior na face póstero-ventral com sete cerdas longas e espaçadas, face postero-dorsal com cinco cerdas espaçadas; tíbia na face posterior com uma longa cerda mediana, face posterior e dorsal com uma pré-apical; pré-tarso longo pouco menor que a soma do comprimento dos demais tarsômeros. Fêmur médio na face anterior com duas cerdas na metade apical, face posterior e póstero-dorsal com uma cerda pré-apical, face póstero-ventral com seis cerdas longas, face ventral com uma série irregular de cerdas curtas; tíbia na face anterior e posterior com uma cerda supra mediana longa; faces ântero-ventral, ventral, póstero-ventral e póstero-dorsal cada uma com uma cerda apical, as 3 últimas mais desenvolvidas, tarsos como na perna anterior. Fêmur posterior com as faces ântero-ventral, póstero-ventral e ântero-dorsal com uma série irregular de cerdas sendo as do terço apical mais longas; tíbias nas faces ântero-ventral, ântero-dorsal e póstero-dorsal com longa cerda no terço médio, face ântero-dorsal e dorsal com uma cerda pré-apical, face ventral com uma cerda apical forte; tarsos como na perna anterior.

Abdômen com cerdas laterais nos tergitos 2 a 5 e discais no tergito 5 .

Terminália (foi dissecado o holótipo, Figs 11 e 12). Cercos mais longos que o epiprocto e de igual comprimento semelhante ao hipoprocto; tergito 66 alargado em toda a sua extensão, tergito 7 afilado, tergito 8 ligeiramente dilatado no ápice. Esternito 6 da mesma largura em toda a extensão, esternito 7 ligeiramente dilatado na base, esternito 8 reduzido a duas pequenas placas sub-triangulares com duas cerdas.

Material examinado. Costa RICA: Higuito (San Mateo), 1 fêmea, sem data, Pablo Schild leg. (USNM).

Registro geográfico. Costa Rica.

\section{Bithoracochaeta plumata Albuquerque, 1955}

Figs $20,27,34,41,48,54,58$

Bithoracochaeta plumata Albuquerque, 1955: 169-172 (desc.). -Albuquerque, 1956: 10 (sin.). - Pont, 1972: 37 (cat., sin.). -Carvalho et al. 1993: 113 (cat., sin.).

Material-tipo. Holótipo macho, etiquetado: "Juiz de Fora/ Salvaterra/ Lopes jan,945"; "HOLÓTIPO" [etiqueta vermelha com bordas pretas]; "4694" [etiqueta manuscrita], "Bithoracochaeta plumata sp.n./ D. Albuquerque det." [etiqueta ma- 
nuscrita de Albuquerque], depositados no Museu Nacional - UFRJ, MNRJ, Rio de Janeiro, Brasil. Em bom estado, abdômen dissecado e montado em lâmina de vidro com a seguinte etiqueta: "Bithoracochaeta plumata sp.n./D. Albuquerque/Holótipo macho" [etiqueta manuscrita de Albuquerque].

Diagnose. Arista com cílos longos em toda extensão. Cerdas catepisternais dispostas como na figura 58. Coxa anterior amarela com a parte posterior castanha.Tíbia posterior com quatro cerdas submedianas: ântero-ventral, ântero-dorsal, póstero-dorsal, póstero-ventral. Hipândrio (Figs 20 e 27) tubular, esclerotinizado, com espinhos curtos.

Coloração. Castanha com polinosidade cinza. Cabeça com parafrontália, parafaciália e gena castanhas com polinosidade prateada; vita frontal castanho escura; antena castanha com polinosidade cinza, ápice do segundo artículo com brilho intenso, palpo castanho amarelado. Mesonoto com uma listra castanho mediana que se estende até o escutelo, duas listras laterais finas coincidentes com as cerdas dorso-centrais; pleuras da mesma cor do mesonoto; caliptra branca; balancim amarelo; asa hialina; coxas castanho-amareladas com polinosidade cinza, trocânteres amarelos, fềmur anterior amarelo com polinosidade cinza na metade basal da face posterior; fêmur médio e posterior, tíbias e tarsos, amarelos. Abdômen castanho com polinosidade cinza, com manchas castanha mediana do segundo ao quinto tergito.

Redescrição. Macho: 5,1 mm. Asa: 4,0 mm.

Cabeça. Olhos afastados entre si no nível do ocelo anterior, cerca de 0,33 vezes a largura da cabeça. Facetas de famanho uniforme. Cerdas frontais longas em número de quatro pares. Antenas inseridas no nível da metade do olho, com o flagelômero medindo cerca de 1,6 vezes o comprimento do segundo. Vibrissas cruzadas, bem desenvolvidas, 1 cerda supra-vibrissal e cerca de cinco cerdas sub-vibrissais.

Tórax. Duas cerdas umerais; uma cerda pós-umeral; uma cerda pré-sutural forte; duas cerdas intra-alares; a anterior ciliforme, uma cerda supra-alar; duas pós-supralares, a posterior maior. Escutelo com um par de cerdas basais, laterais, fino e curto, e um par um pouco mais longo; um par de cerdas apicais fortes, cerca de quatro vezes o comprimento da última. Fêmur anterior na face dorsal com sete cerdas, face póstero-dorsal com cinco cerdas, face ventral com onze cerdas de tamanho irregular; tíbia na face posterior com uma longa cerda mediana, faces ântero-dorsal e dorsal com uma cerda inserida no terço apical, faces póstero-dorsal e posterior com uma cerda pré-apical fina, a última mais longa; pré-tarso longo pouco menor que a soma dos comprimentos dos demais tarsômeros. Fêmur médio na face anterior e ântero-ventral com uma série de cerdas irregulares curtas inseridas nos dois terços basais, face póstero-dorsal e posterior com uma cerda no terço apical, face póstero-ventral com três cerdas longas na região mediana. Tíbias na face anterior com cerdas submedianas longas, face posterior com uma cerda mediana longa, faces póstero-dorsal, póstero-ventral e anterior com uma cerda apical. Tarsos como na perna anterior. Fêmur posterior com a face ântero-dorsal com seis cerdas longas e uma série irregular de cerdas, face póstero-ventral com duas cerdas longas inseridas no terço médio, face póstero-dorsal com uma cerda no terço apical; tíbias 
nas faces ântero-ventral, ântero-dorsal, póstero-dorsal e póstero-ventral com longa cerda no terço médio; face ântero-dorsal com uma cerda pré-apical, face dorsal com uma cerda inserida no terço apical, face ventral com uma cerda apical forte. Tarsos como na perna anterior.

Abdômen. Cerdas laterais nos tergitos 2-5 e discais no tergito 5 .

Terminália (Figs 20, 27, 34, 41 e 48). Placa cercal mais longa do que larga. Apódema do edeago esclerotinizado e longo, envolvidos na metade basal pelo hipândrio tubular, esclerotinizado com curtos espinhos.

Material examinado. BRASIL, Minas Gerais: Juiz de Fora (Salvaterra), 1 macho, I.1945, Lopes leg. (MNRJ); São Paulo: Onda Verde (Faz. São João), 1 macho, I.1946, F. Lane leg. (MNRJ).

Registro geográfico. Brasil (Minas Gerais e São Paulo).

\section{Bithoracochaeta varicornis (Coquillet, 1900)}

Figs $13,14,16,23,33,42,49,60$

Coenosia varicornis Coquillet, 1900: 256 (desc.). - Stein, 1919: 162, 178 (cat.). - Séguy, 1937: 219, 522 (cat.).

Bithoracochaeta varicornis; Malloch, 1934: 327 (coment.). - Hucket, 1934: 61 (coment.). Albuquerque, 1956: 10 (sin.). - Pont, 1972: 37 (cat., sin.). - Carvalho et al. 1993: 113 (cat., sin.).

Material-tipo: holótipo macho, etiquetado: "Vieques I/ Feb 1899"; "Porto Rico/ Aug Busck";"Type No. 4375/U.S.N.M." [etiqueta vermelha]; "Coenosia/varicornis/Coq. [manuscrito]. Em bom estado, asa direita danificada no terço basal. (USNM). Abdômen dissecado e acondicionado em glicerina dentro de tubinho de vidro alfinetado no exemplar.

Parátipo macho, etiquetado: "Vieques I/ Feb 1899"; "Porto Rico/ Aug Busck"; "PType No. 4395/ U.S.N.M." [etiqueta vermelha]. (USNM). Em bom estado, asa direita danificada no terço basal.

Parátipo fềmea, etiquetado: "Vieques I/ Feb 1899"; "Porto Rico/ Aug Busck";"PType No. 4315/ U.S.N.M." [etiquetas vermelha]. (USNM). Falta perna anterior direita e perna média esquerda.

Diagnose. Arista ciliada nos dois terços basais. Cerdas catepisternais dispostas como na figura 60. Tíbia posterior com quatro cerdas submedianas: ântero-ventral, ântero-dorsal, póstero-dorsal, póstero-ventral: placa cercal sem incisão na borda posterior. Hipândrio (Figs 16 e 23) tubular, esclerotinizado, com espinhos curtos. Mesonoto com uma listra central bem nítida que atinge o ápice do escutelo. Triângulo ocelar com polinosidade dourada.

Coloração. Castanha com polinosidade cinza. Parafrontália, parafaciália e gena castanhas com polinosidade prateada; vita frontal castanha, mais escurecida nas fêmeas; antena castanha com os dois terços apicais amarelos nos machos e castanho nas fêmeas, palpo castanho. Mesonoto com uma listra castanha mediana que se estende pelo escutelo, duas listras laterais finas coincidentes com a superfície de cerdas dorso-centrais e duas listras laterais mais largas coincidentes com a superfície de cerdas intra-alares; pleuras da mesma cor do mesonoto; calíptra branca; balancim amarelo claro; asa hialina; coxas castanho-escuras com polinosidade 
cinza, trocânteres castanho- amarelados, fêmures castanho-escuros; articulações fêmoro-tibiais amarelas; tíbias e tarsos mais claros nos machos e da mesma cor dos fềmures nas fêmeas. Abdômen castanho com polinosidade cinza mais intensa na metade superior de cada tergito.

Redescrição. Macho: 4,0 mm. Asa: $3.5 \mathrm{~mm}$.

Cabeça. Olhos afastados entre si no nível do ocelo anterior cerca de 0,33 vezes a largura da cabeça; facetas de tamanho uniforme. Cerdas frontais longas e fortes, em número de quatro pares. Antena inserida no nível da metade dos olhos, flagelômero medindo cerca de 1,9 vezes o segundo; parafaciália estreita semelhante a largura da gena ao nível inferior do olho. Vibrissa longa e forte; uma cerda supravibrissal duas cerdas subvibrissais.

Tórax. Duas cerdas umerais; cerda pós-umeral pouco desenvolvida; uma pré-sutural; duas intra-alares; uma supralar; duas pós-supralar. Escutelo com um par de cerdas basais laterais, fino e curto; um par longo abaixo deste um pouco mais dessenvolvido; e um par de cerdas apicais fortes, cerca de 3 vezes o comprimento da anterior. Fêmur anterior nas faces póstero-ventral e póstero-dorsal com uma série irregular de cerdas; tíbia na face posterior com uma longa cerda mediana, faces dorsal, ântero-dorsal e póstero-dorsal com uma cerda pré-apical fina, a última, a mais longa; pré-tarso longo pouco menor que a soma do comprimento dos demais tarsômeros. Fêmur médio na face anterior com cerca de 3 cerdas uma em cada terço, face ântero-dorsal com uma longa cerda inserida no terço basal, face ântero-ventral com uma série de cerdas curtas nos $2 / 3$ basais, face póstero-ventral com cerca de quatro cerdas longas inseridas medianamente; tíbia nas faces anterior e posterior com uma cerda mediana forte, faces póstero-dorsal, póstero-ventral e ventral com uma cerda apical, a última mais desenvolvida; tarsos, como na perna anterior. Fêmur posterior nas faces ântero-dorsal e póstero-ventral com uma série irregular de cerdas; tíbia nas faces ântero-ventral, ântero-dorsal, póstero-dorsal e póstero-ventral com longa cerda mediana, faces ântero-dorsal e dorsal com uma cerda pré-apical, face ventral com cerda apical. Tarsos, como na perna anterior.

Abdômen. Cerdas laterais nos tergitos 2 a 5 e discais no tergito 5 .

Terminália (foi dissecado o parátipo, Figs 16, 23, 33, 42 e 49): placa cercal mais longa do que larga, borda anterior com uma incisão, borda posterior sem incisão, surstilos com o ápice arredondado. Apódema do edeago esclerotinizado e longo, envolvido nos dois terços basais pelo hipândrio tubular, pouco esclerotinizado com curtos espinhos. Parâmeros curtos e arredondados.

Fêmea. 5,0 mm. Asa 4,0 mm.

Semelhante ao macho, diferindo no que segue: coloração geral mais escurecida principalmente nas antenas e pernas.

Terminália (dissecado o parátipo): cercos mais longos que o epiprocto e de comprimento semelhante ao hipoprocto; tergito 6 ligeiramente alargado na base, tergito 7 afilado e longo, tergito 8 ligeiramente alargado no ápice. Esternitos 6 e 7 em forma de bastão, dilatados no ápice, a metade apical pouco esclerotinizada; esternito 8 reduzido a duas pequenas placas sub-triangulares com 2 cerdas cada um. 
Material examinado. PorTo Rico: Vieques Islands, 1 macho, II.1899, Aug. Busck leg. (USNM); 1 fềmea, II.1899, Aug. Busck leg. (USNM). Brasil, Paraná: Dorado, 1 fêmea, 3-VII.1934, sem coletor (MNRJ); Santa Catarina: Seara (Nova Teutônia), 1 fêmea, 15-XI.1936, Fritz Plaumann leg. (BMNH).

Registro geográfico. Porto Rico, Brasil (Paraná, Santa Catarina).

AGRADECIMENTOS. Agradecemos aos Doutores Brian Pittkin, Claudio José Barros de Carvalho, Raymond J. Gagné e Verner Michelsen pelo empréstimo de material, pertencente respectivamente ao The Natural History Museum, Londres, Inglaterra, Universidade Federal do Paraná, Curitiba, Paraná, Brasil, United States National Museum, Washington, D.C., EUA e Zoologisk Museum, Universitets Copenhagen, Copenhagen, Dinamarca. A Dra Denise Pamplona pelas sugestões e leitura critica do manuscrito.

\section{REFERÊNCIAS BIBLIOGRÁFICAS}

Albuquerque, D.O. 1955. Nova espécie de Bithoracochaeta Stein (Diptera Muscidae). Revta bras. Ent. 3: 169-172.

- 1956. Contribuição ao conhecimento de Bithoracochaeta Stein, 1911 (Diptera-Muscidae). Bol. Mus. Nac. Rio Janeiro, Zoologia, 149: 1-17.

BigOT, J.M. 1885. Diptères nouveaux on peu connus $25^{\text {eme }}$ partie XXXIII. Anthomyzides nouvelles. Annls. Soc. ent. Fr. 4 (6): 263-304.

Blanchard, E.E. 1937. Dipteros Argentinos Nuevos o Poco Conocidos. Revta Soc. ent. argent. 9: 35-58.

CARvalHo, C.J.B. DE. 1989. Classificação de Muscidae (Diptera): uma proposta através da análise cladística. Revta bras. Zool. 6: 627-648.

CARvalho, C.J.B. DE \& M.S. Couri. 1992. Muscidae, Fanniidae e Calliphoridae (Diptera) do Projeto Maracá, Roraima, Brasil. Acta Amazonica 21: 35-43.

Carvalho, C.J.B. DE; A.C. Pont; M.S. Couri \& D. Pamplona. 1993. Muscidae. In: A Catalogue of the Fanniidae and Muscidae (Diptera) of the Neotropical Region. Part II. Sociedade Brasileira de Entomologia, São Paulo, $201 \mathrm{p}$.

Coquilet, D.W. 1900. Report on a collection of Dipterous insectes from Puerto Rico. Proc. U.S. Nat. Mus. $22: 249-270$.

COURI, M.S. \& S.M. LOPES. 1985. Neotropical Genera of Coenosiinae - Nomeclatural Notes and Key to identification (Diptera-Muscidae). Rev. Brasil. Biol. 45: 585-595.

Couri, M.S. \& H.C.G. MotTA. 1994. Uma Nova Espécie de Bithoracochaeta Stein, 1911 (Diptera, Muscidae, Coenosiinae). Revta bras. Zool. 11: 211-214.

Curran, C.H. 1928. Insects of Porto Rico and Virgin Islands. Diptera or two winged flies. Scientific Survey of Porto Rico and the Virgini Islands 11: 1-118.

1934. The Diptera of Kartabo, Bartica District, British Guiana, with descriptions of new species from other British Guiana localities. Bull. Amer. Mus. Nat. Hist. 66: 287-532.

ENGEL, E.O. 1931. Die Ausbeute der deutschen Chaco-Expedition 1925/26. Diptera. XXVI. Anthomyiidae. XXVII. Muscidae und XXVIII. Sarcophagidae. Konowia 10: 133-154. 
Garcia, P.C. 1964. Moscas de Venezuela. Caracas, 17 páginas sem numeração. Giglio-Tos, H. 1894. Diagnosi di nuovi generi e nuove specie di Ditteri. VIII. Boll.

Musei Zool. Anat. comp. R. Univ. Torino 8 (147): 1-11.

Gowdey, G.C. 1926. Catalogus Insectorum Jamaicensis. Ent. Bull. Dep. Agric. Jamaica 4: 114+XIV, 10+II.

HuCKETT, H,C. 1934. A revision of the North American species belonging to the genus Coenosia Meigen and related genera. (Diptera Muscidae) Part I. The subgenera Neodexiopsis, Coenosia, Hoplogaster and related genera Allognota, Bithoracochaeta and Schoenomyza. Trans. Amer. Ent. Soc. 60: 57-119. . 1965. Muscidae, p.869-915. In: A. Stone; C.W. SAbrosky; W.W. WIRTH; R.H. FoOTE \& J. COULSON (Eds). A Catalog of the Diptera of America North of Mexico. Washington, D.C., U.S. Dep. Agric. Handbook 276: IV+ $1696 p$.

MALLOCH, J.R. 1921. Notes on some of van der Wulp' species of north American. Anthomyidae (Diptera). Ent. News, Londres, 32: 40-45.

- 1934. Muscidae. In: Diptera of Patagonia and South Chile. London, 7 (2), p. 171-346.

MCALPINE, J.R. 1981. Morphology and Terminology, p.9-63. In: J.F. MCALPINE (Ed.). Manual of Neartic Diptera. Otawa, Agriculture Canada, Research Branch, Monograph 27, Vol. 1, VI+674p.

MotTA, H.C.G. \& M.S. CoURI. 1995. Redescrição de Bithoracochaeta Stein, com comentários sobre sua posição sistemática. (Diptera, Muscidae). Revta bras. Zool. 12: 47-53.

. (no prelo). Revalidação Bithoracochaeta atricornis Malloch, 1934 (Diptera, Muscidae, Coenosiinae). Revta bras. Ent.

Pont, A.C. 1972. Family Muscidae. In: N. PAPAvero (Ed.). Catalogue of the

Diptera of the Americas South of United States, 97. São Paulo, Museu de Zoologia, Universidade de São Paulo, $111 \mathrm{p}$.

SÉGuY, E. 1937. Diptera Fam. Muscidae. In: P. Wytsman (Ed.). Genera Insectorum 205. Bruxelas, $604 \mathrm{p}$.

STEIN, P. 1898. Nordamerikanisch Anthomyiden Beitrag zur Dipterenfaunna der Vereinigten Staaten. Berl. ent. Z. 42: 161-288.

1901. Die Walker'schen ausserenropäischen Anthomyiden in der Sammlung des British Museum zu London (Dipt.). Z. syst. Hymenopt. Dipterol. 1: 185-221.

. 1904. Die Amerikanischen Anthomyiden des Königlichen Museums für Naturkunde zu Berlin und des Ungarischen National Museums zu Budapest. Ann. hist. nat. Mus. natn. hung. 2: 414-495.

- 1910. Die Thomson beschriebenen Anthomyiden der Eugenies Resa. Wien. ent. Ztg. 29: 66-78.

- 1911. Die von Schnuse in Sudamerika gefangenen Anthomyiden. Arch. Naturgesch. 77 (1): 61-169.

- 1919. Die Anthomyidengattungen der Welt, analytisch bearbeitet, nebst einem kritisch-systematischen Verzeichnis aller aussereuropäische Arten. Arch. Naturgesch. 83 A1: 85-178.

- 1920. Nordamerikanische Anthomyiden. 2. Beitrag. Arch. Naturgesch. 
84 A9: 1-106.

Thomson, C.G. 1869. Diptera. Species nova descripsit. In: Kongliga Svenska Fregatten Eugenis Resa Omkring Jorden under befäl af C.A. Virgin, àren 1851-1853. Part 2, Zoologi, 1, Insecta: 58-617, Estocolmo.

TownSEND, C.H.T. 1892. Catalogue of the described South American Species of Calyptrate Muscidae. Ann. N.Y. Acad. Sci. 7: 1-44.

WALKER, F. 1853. Insecta Saundersiana or characteres of undescribed insects in the collection of Willian Wilson Saunders. Esq., F.R.S., F.L.S. \& c. Londres, Vol. 1, Diptera [part 4], p.253-414.

WiedEMANN, C.R. 1830. Aussereupäischen Zweiflügelige Insekten Part II: $\mathrm{XII}+684+\mathrm{XIp}$.

WolcotT, G.N. 1924. "Insectae Portiricensis". A preliminary annotated check-list of insects of Porto Rico, with descriptions of some new species. Jour. Dep. Agric. P. Rico 7: 1-313.

- 1936. "Insectae Borinquenses". A Revised annotated check-list of insects of Porto Rico. Jour. Agric. Univ. P. Rico 20, p.627+3p.

- 1948. The Insects of Puerto Rico. Diptera. Jour. Agric. Univ. P. Rico 32: 417-532.

WULP, F.M. VAN DER. 1896. Group Anthomyiiinae, In: F.D. GODMAN; F. D. \& O. SALvin (Eds). Biologia Centrali Americana. Londres, p.321-344.

Recebido em 19.II.1998; aceito em 26.V.1999. 